\title{
Significant Differences in Natural Killer Cell Activity in Children According to Age and Sex
}

\author{
TAMAKI HORIKOSHI \\ Department of Pediatrics, Kurume University School of Medicine, Kurume, 830 and \\ Section of Pediatrics, Kyushu Cancer Center, Fukuoka, 815 Japan
}

Received for publication January 22, 1985

\begin{abstract}
Summary: Peripheral blood mononuclear cells from 45 children, aged 1 to 19 years were evaluated for natural killer cell cytotoxic activity against K-562 erythroleukemic cells. The results of a ${ }^{51} \mathrm{Cr}$ release assay demonstrated that the NK cell activity of normal children is dependent on age and sex. Younger females, aged 1 to 9 years, were more reactive than elder females aged between 10 and 19 years $(P<0.001)$. Males aged 1 to 19 years were less reactive than adults $(0.02<P<0.05)$. Among children, the levels of NK cell activity were significantly greater in females than in males $(0.001<\mathrm{P}<0.01)$. In contrast, among elder children, the levels of NK cell activity were significantly greater in males than in females $(0.01<\mathrm{P}<0.02)$. The NK cell activity of elder female children was $60 \%$ and $59 \%$ that of the elder male children, at the two $\mathrm{E}: \mathrm{T}$ ratios of $50: 1$ and $100: 1$, respectively.
\end{abstract}

Key words : natural killer cell-cytotoxicity-peripheral blood mononuclear cell - age-related difference-sex-related difference

\section{Introduction}

The existence of natural killer cell cytotoxicity as a phenomenon was initially disputed, as an artifact of the assay but was finally confirmed as a distinct reproducible form of cytotoxicity mediated by a definable subclass of effector cells. Natural killer cells have the unique ability to recognize, without prior sensitization, nonantibody-coated targets and to spontaneously lyse these allogeneic, syngeneic, and xenogeneic tumor cells (Herberman et al. 1979). The capability to nonspecifically detect and eliminate foreign cells upon in- itial exposure has led to the proposal that natural killer function is the primary effector of the immunosurveillance (Herberman et al. 1979; Lotzova and McCredie, 1978; Pross and Baines, 1977).

There is increasing evidence that natural killer cells may play an important role in resistance against tumor cell growth and also in bone marrow transplants (Goleik et al. 1982; Warner and Dennert, 1982). In mice and rats, the levels of natural killer cell activities follow a characteristic age-related pattern. The cells possessing natural killing activity first appear at 3-4 weeks of age, reach a peak level between

Present address and reprints request to: Department of Pediatrics, Kurume University School of Medicine, Asahi-machi 67, Kurume, 830 Japan.

The abbreviations used are: NK, natural killer; RPMI, Roswell Park Memorial Institute; FCS, fetal calf serum; MEM, minimum essential medium; ALL, acute lymphoblastic leukemia.

This work was supported in part by a Grant-in-Aid for Cancer Research (56-23) from the Ministry of Health and Welfare. 
5-10 weeks of age, and then decline to low levels thereafter. There are also considerable differences in levels of activity among various strains of animals (Stutman, 1980). Reports of levels of human natural killer cell activity according to age and sex are controversial (Forbes et al. 1980; Herberman et al. 1979; Nagel et al. 1981; Penschow and Mackay, 1980) and studies dealing with natural killer cell cytotoxicity in children under 10 years of age are not well documented.

This paper therefore describes the natural killer cell activity of peripheral blood mononuclear cells in normal children and the results are compared with that of normal adult group.

\section{Materials and Methods}

\section{Study Population}

The Population studied was composed of 45 children ( 23 females and 22 males) and 10 adults. This group included normal children, children with congenital heart disease (CHD), and healthy adults. The types of CHD were atrial septal defect (ASD), ventricular septal defect (VSD), and patent ductus arteriosus (PDA). Children and adults were screened to exclude those with a history of viral infection less than three weeks prior to testing and those with a personal history of neoplastic or other serious disorders.

\section{Effector Cells}

The children with CHD were given cephalexin $(50 \mathrm{mg} / \mathrm{kg}$ p. o. ) one day before cardiac catheterization and hydroxyzine hydrochloride ( $2 \mathrm{mg} / \mathrm{kg}$ i.m. ), pethidine hydrochloride ( $1 \mathrm{mg} / \mathrm{kg} \mathrm{s.c.})$ and ketamine hydrochloride $(5 \mathrm{mg} / \mathrm{kg}$ i. $\mathrm{m}$. ) prior to the tests. In children with $\mathrm{CHD}$, blood samples were drawn at the time of pre- or postoperative cardiac catheterization. Peripheral blood mononuclear cells were isolated on a Ficoll-Conray Gradient and washed three times in phosphate buffered saline (PBS). To remove adherent mononuclear cells, the cell suspension was incubated in plastic tissue culture dishes No. 3002 (Falcon Plastics Co., U.S. A. ) for one hour at $37^{\circ} \mathrm{C}$ in MEM with $10 \%$ heat-inactivated fetal calf serum. Non-adherent cells were washed twice in MEM-10 \% FCS and adjusted to final concentrations of 1,5 or $10 \times 10^{6}$ cells $/ \mathrm{ml}$.

\section{Target Cells}

K-562 cell line was generously supplied by Dr. Hiromitsu Okano, Kyushu Cancer Center.

The cell line was maintained as a stationary suspension culture in RPMI-1640 medium supplemented with $10 \%$ FCS, $0.1 \mathrm{~g}$ kanamycin and $2.0 \mathrm{~g}$ sodium bicarbonate. K-562 target cells were washed once in culture medium and the supernatant was aspirated. Tris-phosphate buffer, 0.2 $\mathrm{ml}$ of $5 \%$ FCS ( $\mathrm{pH} 7.4$ ) was added to the pellet followed by addition of $0.1 \mathrm{ml} \mathrm{Na}_{2}$ ${ }^{51} \mathrm{CrO}_{4}$ solution $(1 \mathrm{mCi} / \mathrm{ml}$, specific activity $200 \mathrm{mCi} / \mathrm{mg}$ ) per $2 \times 10^{6}$ target cells and incubated at $37^{\circ} \mathrm{C}$ for $45 \mathrm{~min}$. The labelled cells were then washed three times in MEM-10\% FCS with absolute minimum pipetting and finally adjusted to $1 \times 10^{5}$ cells $/ \mathrm{ml}$.

\section{Cytotoxicity assay}

Radio-labelled target cells $\left(1 \times 10^{4}\right)$ were dispensed into test tubes (Sumitomo Bakelite Co., JAPAN). Three different sets of effector with target cell ratios of $100: 1$, $50: 1$ and $10: 1$ were used and each ratio was run in triplicate. Following the addition of the target cells, the tubes were centrifuged for $3 \mathrm{~min}$ at $200 \times \mathrm{g}$ and then incubated at $37^{\circ} \mathrm{C}$ in a humidified atmosphere containing $5 \% \mathrm{CO}_{2}$ and $95 \%$ air. After 3-hours' incubation, the tubes were centrifuged for $5 \mathrm{~min}$ at $600 \times \mathrm{g}$. Supernatants were removed, and placed in individual polyethylene culture tubes $(12 \times 75$ $\mathrm{mm}$ ) and the radioactivity determined in a 
gamma counter (Aloca. Auto Well Gamma System ARC 505 R. SERIAL No. RW10089).

The percentage of specific ${ }^{51} \mathrm{Cr}$ release was calculated as $\%$ of ${ }^{51} \mathrm{Cr}$ release $=$

experimental release-spontaneous release

maximal release - spontaneous release $\times 100$

The above formula indicates that experimental release was determined with the presence of effector cells.

Spontaneous release was determined by incubation of target cells in medium without effector cells resulting in less than $20 \%$ of the maximal release. The maximal release was determined by measuring counts per min (cpm) in the supernatant after detergent lysis of the target cells with $1 \%$ Triton $\times 100$.

\section{Results}

\section{Effect of Age and Sex on NK Cell Activity}

The NK cell activity of peripheral blood lymphocytes from 45 children against K-562 target cells is shown in Fig. 1. The degree of cytotoxicity of the mononuclear cells obtained from young females, aged 1 to 9 years, was much higher than those of the teenage group. The results were found to be statistically significant $(\mathrm{P}<0.001)$. In males, there was no significant difference between the two groups. In children, however, the level of NK cell activity was significantly higher in females than in males $(0.001<\mathrm{P}<0.01)$. In contrast, among teenagers, the level of NK cell activity was significantly higher in males than in females $(0.01<\mathrm{P}<0.02)$. The NK cell activity of teenage females was $60 \%$ and $59 \%$ of that of males, at the two $\mathrm{E}: \mathrm{T}$ ratios of $50: 1$ and $100: 1$ respectively. Males, aged 1 to 19 years, were less reactive than adults $(0.02<\mathrm{P}<0.05)$.

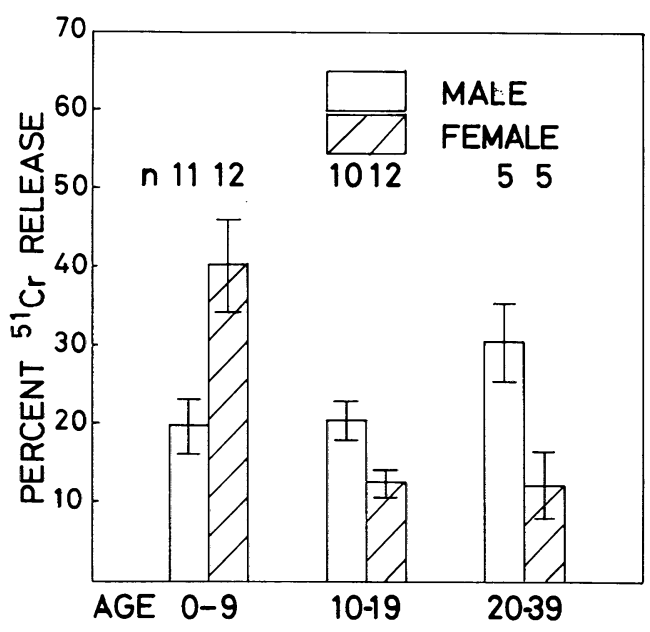

Fig. 1. Geometric mean percentage of ${ }^{51} \mathrm{Cr}$ release at a 50:1 effector: target ratio by age group and sex. Radiolabelled K-562 target cells were incubated $3 \mathrm{hr}$ as described in Materials and Methods. $\square$, Percentage of NK cell activity of males; $Z Z D$, Percentage of NK cell activity of females; bars, S. E. The NK cell activity of normal individuals is age and sex-dependent. Number of individuals in each age group is represented by $n$.

\section{NK Cell Activity of Children with and with- out premedication}

There was no significant difference in NK cell activity between the groups of children with and without premedication, as determined by Student's t-test (Fig. 2).

\section{Longitudinal Follow-up of NK Cell Activity}

Fig. 3. displays the results of two separate measurements of $\mathrm{NK}$ cell activity on the same individuals taken 2 to 9 (mean, 5.6) months apart. Although the sample size was small $(n=12)$, considerable variation among individuals in levels of NK cell activity was found and no statistical difference by paired $t$-test analysis was noticed between the first and second determinations of NK cell activity. 


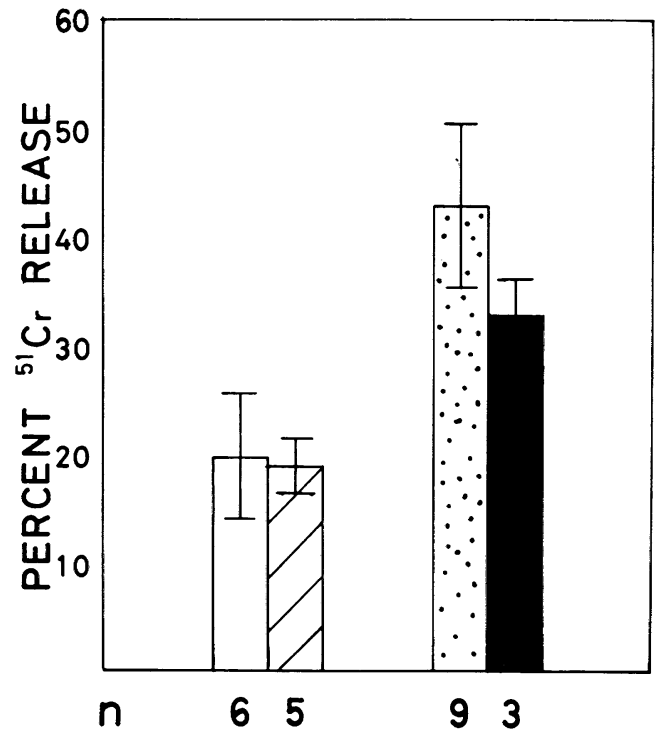

Fig. 2. NK cell activity of children under 10 years of age with and without premedication.

$\square$, NK cell activity of boys receiving premedication; $R \backslash \triangle$, NK cell activity of boys without it; $\because$, NK cell activity of girls receiving premedication;, NK cell activity of girls without it; bars, S.E. By $\mathrm{t}$-test, there were no significant differences in NK cell activity between the group of children with premedication and the group of children without it. Number of individuals in each group is represented by $n$.

\section{Discussion}

In the present study, the effect of age and sex on levels of cytotoxic NK cell activity in peripheral blood mononuclear cells was studied. The results obtained indicate that the degree of NK cell activity against the K-562 cell line is age and sex dependent. The NK cell cytotoxicity of female children was high, and then declined to lower values following an increase in age, while in males, the level of NK cell activity reached the highest levels at over 20 years of age. Herberman et al. (1979) have reported that $\mathrm{NK}$ cell activity was

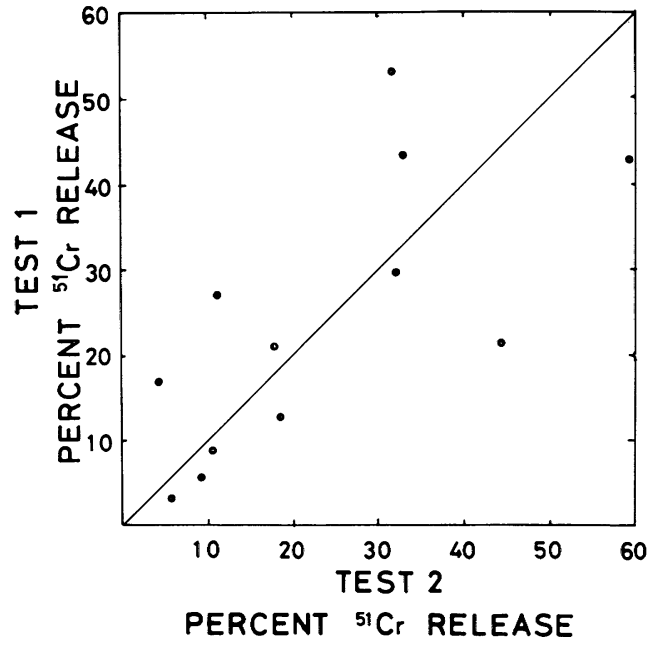

Fig. 3. Percentage of ${ }^{51} \mathrm{Cr}$ release at a $50: 1$ effector: target ratio of cells. The same individual was tested on 2 separate occations. Mean interval between the tests was 5.6 months (range, 2 to 9 months). By paired $t$-test, there were no significant differences in NK cell activity in this time interval.

relatively stable among various age groups and Nagel et al. (1981) also reported a lack of significant age-related difference in NK cell activity against K-562 cells. Penshow and Mackay (1980), utilizing the Chang cell-line as target, reported that NK cell activity was greater in youth, ages 20 to 39, and Forbes et al. (1980) using K-562 cell line as target, reported greater NK cell activity in young males, aged 11 to 20 years, than in males of 21 to 50 years of age. However, most published data have dealt with either adults or children over 10 years of age, although the results of previous reports vary.

The NK cell cytotoxicity of the females, ages 20 to 39 , was $39 \%$ and $43 \%$ that of the males with in the same age group at $\mathrm{E}: \mathrm{T}$ ratios of $50: 1$ and $100: 1$, respectively, and this difference was found to be statistically significant $(0.02<\mathrm{P}<0.05)$. The NK cell activity of teenage females was 
$60 \%$ and $59 \%$ that of teenage males, at $\mathrm{E}: \mathrm{T}$ ratios of $50: 1$ and $100: 1$, respectively. In contrast, the NK cell activity of male children was $48 \%$ and $62 \%$ that of the female children, at $\mathrm{E}: \mathrm{T}$ ratios of $50: 1$ and $100: 1$, respectively.

The results suggest that sex hormones may have some influence on the effector cell activity in normal individuals. Estrogen is also one of the cAMP elevating agents and the hormone may act as a suppressive agent of NK cell activity (Roder and Klein, 1979). The estrogen level increases after approximately 11 years of age in females, but in males there is no increase during puberty (Sizonenko, 1978). Our present data seem to be compatible with those physiological conditions based on sex. Santoli et al. (1976) reported that lymphocytes from male donors were about twice as effective as those from female donors in NK cell activity. Forbes et al. (1980) reported that among an older age group, males were slightly more reactive than females, but there were no statistically significant difference in cytotoxity associated with sex. Nagel et al. (1981) reported the absence of a statistically significant sex-related difference in NK cell activity against the $\mathrm{K}-562$ cell line.

Many reports dealing with human NK cell activity according to age and sex have been reported, however, the results have varied significantly and the level of human NK cell activity among normal subjects within the same age group has been variable. In addition, the laboratory procedures for assessment of NK and $\mathrm{K}$ cell activities were far from standardised and methodological variability including the target cell and $\mathrm{E}: \mathrm{T}$ ratio used could invalidate comparisons of published data. Failure to dissociate effects attributable to $\mathrm{NK}$ and $\mathrm{K}$ cell cytotoxicity, the influence of sex and age and other factors affecting NK cell activity must also be considered. In addition the activity has been reported to be influenced by HLA haplotype, viral and other infections (Hauser et al. 1982; Herberman and Holden, 1978; Petranyi et al. 1974). Interferon is known to mediate the immune modulation of $\mathrm{NK}$ cell cytotoxic activity.

NK cells may be augmented by interferon via recruitment of pre-NK cells (Saksela et al. 1979) or interferon may act mainly to accelerate the rate of lysis by activated NK cells.

In immunosurveillance, NK cells may play an important role in resistance against tumor growth in the early stages. Macrophages are also known to elicit spontaneous cytotoxic activity against tumor cells (Herberman et al. 1979). T-cell immunity may be a relatively late event and play a more important role in further resistance to progressive tumor growth (Herberman et al. 1979).

In recent years, several investigators reported NK cell activity in a small number of children with acute lymphoblastic leukemia and the results were compared with a normal control group (McGeorge et al. 1982; Oldham et al. 1976; Tanaka, 1981). In acute leukemia, approximately $40 \%$ of the cases occured in children between 3 and 5 years of age and Cook's series revealed a predominance of males over females in all except the first year of the life (Cooke, 1942). In our study, female children were found to have greater NK cell cytotoxicity than male children. This difference in NK cell activity of children under 10 years of age may have some influence on the incidence of acute leukemia. In experimental studies, the incidence of radiation-induced thymic leukemia in $\mathrm{C} 5$ $7 \mathrm{BL} / 6$ mice was dramatically reduced by intravenous administration of syngeneic cloned NK cells (Warner and Dennert, 1982) and neuroblastoma spontaneously regressed in 5-10\% of cases. In routine autopsies of infants under 3 months of age, neuroblastoma in situ in the adrenal is seen 40 times more frequently than expected, suggesting a high rate of spon- 
tanous regression or differentiation (Beckwith and Perrin, 1963).

It would be of interest to examine the levels of NK cell activity of normal children under 10 years of age and in children with acute leukemia or neuroblastoma.

To clarify NK cell activity according to age and sex, more extensive and longterm observations are needed.

Acknowledgments: Grateful acknowledgment is made to Prof. F. Yamashita for his constant interest and guidance in this investigation. The author expresses appreciation to Prof. Mitchel M. Yokoyama for his critical review, valuable advice and help in preparation of this manuscript. Prof. H. Kato kindly permitted study of patients under his care. The autthor wishes to thank H. Tasaka, M.D., and H. Mashiba, M.D. for their valuable comments and advice.

\section{References}

Beckwith, J. B. and Perrin, E. V. (1963). In situ neuroblastoma: A contribution to the natural history of neural crest tumors. Am. J. Pathol. 43, 1089-1104.

Cooke, J. V. (1942). Incidence of acute leukemia in children. J. A. M. A. 119, 547-550.

Forbes, J. T., Greco, F. A. and Oldham, R. K. (1980). Natural cell-mediated cytotoxicity in human tumor patients. In R. B. Herberman (ed). Natural cell-mediated immunity against tumors. p. 1031-1046. New York: Academic Press, Inc.

Goleik, E., Wiltrout, R. H., Okumura, K., Habu, S. and Herberman, R. B. (1982). Role of NK cells in the control of metastatic spread and growth of tumor cells in mice. Int. J. Cancer, 30, 107-112.

Hauser, W.E., Sharma, Jr.S. D. and Pemingston, J.S. (1982). Natural killer cells induced by acute and chronic toxoplasma infection. Cell. Immunol. 69, 330-346.

Herberman, R. B. and Holden, H. T. (1978). Natural cell-mediated immunity. Adv. Cancer Res. 27, 305-377.

Herberman, R. B., DJeu, J. Y., Kay, H. D., Ortaldo, J. R., Riccardi, C., Bonnard, G. D., Holden, H. T., Fagnani, R., Santoni, A. and Puccetti, P.
(1979). Natural killer cells: Characteristics and regulation of activity. Immunol. Rev. $44,43-70$.

Lotzova, E, and McCredie, K. B. (1978). Natural killer cells in mice and man and their possible biological significance. Cancer Immunol. Immunother. 4, 215-221.

McGeorge, M. B., Russel, E. C. and Mohanakumar, T. (1982). Immunologic evaluation of longterm effects of childhood ALL chemotherapy: Analysis of in vitro NK- and $\mathrm{K}$-cell activities of peripheral blood lymphocytes. Am. J. Hematol. 12, 19-27.

Nagel, J. E., Collins, G. D. and Adler, W. H. (1981). Spontaneous or natural killer cytotoxicity of K-562 erythroleukemic cells in normal patients. Cancer Res. 41, 2284-2288.

Oldham, R. K., Weiner, R.S., Mathê, G., Breard, J., Simmler, M. C., Carde, P. and Herberman, R. B. (1976). Cell-mediated immune responsiveness of patients with acute lymphoblastic leukemia in remission. Int. J. Cancer, 17, 326-337.

Penschow, J. and Mackay, I. R. (1980). NK and $\mathrm{K}$ cell activity of human blood: differences according to sex, age, and disease. Ann. Rheum. Dis, 39, 82-86.

Petranyi, G., Ivanyi, P. and Hollan, S. R. (1974). Relations of HLA and Rh systems to immune activity. Vox. Sang. 26, 470-482.

Pross, H.F. and Baines, M. G. (1977). Spontaneous human lymphocyte mediated cytotoxicity against tumor target cells. VI. A brief review. Cancer Immunol. Immunother. 3, 75-85.

Roder, J.C. and Klein, M. (1979). Target-ef fector interaction in the natural killer cell system. IV. Modulation by cyclic nucleotides. J. Immunol. 123, 2785-2790.

Saksela, E., Timonen, T. and Cantell, K. (1979). Human natural killer cell activity is augmented by interferon via recruitment of preNK cells. Scand. J. Immunol. 10, 257-266.

Santoli, D., Trinchieri, G., Zmijewski, C. M. and Koprowski, H. (1976). HLA-related control of spontaneous and antibody-dependent cellmediated cytotoxic activity in humans. J. Immunol. 117, 765-770.

Sizonenko, P.C. (1978). Endocrinology in preadolescents and adolescents. I. Hormonal changes during normal puberty. Am. J. Dis. Child, 132, 704-711. 
Stutman, O. (1980). Ontogeny and other age related effects of natural cytotoxic (NK) cells in mice. In R. B. Herberman Natural cellmediated Immunity against tumors. p. 231240. New York: Academic Press.

TANAKA, Y. (1981). Natural killer (NK) activity in children with acute lymphoblastic leuke- mia. Hiroshima. J. Med. Sciences, 30, 127133.

Warner, J. F. and Dennert, G. (1982). Effect of a cloned cell line with NK activity on bone marrow transplants, tumor development and metastasis in vivo. Nature, 300, 31-34. 